\title{
MODERN LEGAL DEFINITION OF HUMAN HEALTH
}

\author{
Lìga Mazure \\ Rezekne Academy of Technologies, Latvia
}

\begin{abstract}
The World Health Organisation has proposed an innovative view on the legal definition of human health, which countries have borrowed and included in their national laws and regulations. At the beginning the legal definition of human health was seen as an innovation and a progressive view on the legal understanding of human health. However, nowadays this legal definition of human health is considered too narrow and needs to be specified in two areas. Firstly, the legal definition of human health should include significant and already existing health principles for objective and comprehensive interpretation. Secondly, nowadays, a more detailed evaluation of the notion of health broadens its interpretation, revealing new aspects of the definition of human health. The research aim is to analyse the legal definition of human health and propose its more specific version in accordance with the modern legal system. The following main research methods of the legal science were used: analytical, systemic, teleological.
\end{abstract}

Keywords: health, human, legal definition, legal system, principles.

\section{Introduction}

The World Health Organisation (hereinafter - WHO) has proposed an innovative view on the legal definition of human health, which countries have borrowed and included in their national laws and regulations. At the beginning the legal definition of human health was seen as an innovation and a progressive view on the legal understanding of human health.

However, nowadays this legal definition of human health is considered too narrow and needs to be specified.

The research aim is to analyse the legal definition of human health and propose its more specific version in accordance with the modern legal system. The following main research methods of the legal science were used: analytical, systemic, teleological.

\section{Literature review}

Literature, laws and regulations and legal practice materials were used in the research process. Considering that the definition of human health is not covered in the Latvian legal science, foreign sources were used primarily. Foreign studies cover certain issues of the definition of human health, without providing a 
comprehensive legal view on the understanding of human health or proposing its specific legal definition.

\section{Methodology}

Special legal science research methods were used in the research process: the semantic, grammatical, analytical, historical, comparative, systemic, and teleological method.

\section{Discussion}

The WHO has made a significant contribution to the formulation of the modern legal definition of human health. Soon after the WWII the WHO defined health in its constitution as "a state of complete physical, mental and social wellbeing", specifying that health is "not merely the absence of disease or infirmity" (Constitution of the World Health Organization, 1946); this definition was also stressed in a later period (The Ottawa Charter for Health Promotion, 1986). The proposed definition of health is characterised by 4 main features: 1) health is described as a category only characteristic of humans; 2) health is opposed to disease, excluding the presence of health disorders in case of health (Health, 2019a); 3) the notion of health also includes the element of social well-being as a prerequisite for health and a result to be achieved in relation to health (Jakarta Declaration on Leading Health Promotion into the 21st Century, 1997; Rogers, Castree, \& Kitchin, 2013; Svalastog, Donev, Kristoffersen, \& Gajovič, 2017); 4) health is equated to a state of absolute well-being. Considering that this definition of health was not legally binding (Habersack \& Luschin, 2013), countries borrowed it and included in their national laws and regulations (e.g.: Ārstniecības likums, 1997; Veterans Health Care Regulations, 1990). Thus, the definition of health proposed by the WHO acquired a binding nature, becoming the content of national laws and regulations.

Although the definition of health by the WHO is seen as an innovative view on the understanding of human health, nowadays it needs to be corrected. Legal arguments are found that promote the necessity to improve the legal definition of human health.

Health is defined as a state of absolute well-being. Such approach is criticised, stating that it is an utopian vision with an unachievable, practically nonexistent result (Misselbrook, 2014; Ottendörfer, 2016; Gangl, 2015; Habersack \& Luschin, 2013). This raises the question - what actual level of well-being is required to define health. Countries tend to determine the minimum threshold of basic needs and provide for measures to avoid harm to health or life, recognising health as one of the most important objective elements of well-being 
(Büchs \& Koch, 2019; Nordenfelt, 2007). And by implementing these measures, it is possible to achieve the required level of well-being for health, without denying the opportunity to achieve a higher level of well-being. It can thus be concluded that health is a complete rather than an absolute state, where its objectively achievable result may differ.

Based on the definition of human health by the WHO, health is opposed to disease, recognising these as absolute and mutually exclusive categories. This raises the question whether health can still be defined for a person with health disorders and whether a person with health disorders can be considered healthy. On the one hand, there is an opinion that health is a state of existence which includes health disorders if a person is able to develop and perform everyday requirements and which also depends on everyone's own beliefs and perception whether one is healthy or ill (Misselbrook, 2014; Sartorius, 2006; Müller; Schramme, 2012). On the other hand, health is also assessed as a state of being in relation to others (Gangl, 2015) where society defines whether a person is considered to be healthy. Middle ground is the most appropriate. After all, health is a person's internal category characterised by the ability to fulfil social obligations while being in harmony with their own and public values (Ibeneme, Eni, Ezuma, \& Fortwengel, 2017; Lock, Last, \& Dunea, 2006; Sartorius, 2006). However, if there is danger to society, it is largely in the interest of society to determine what conditions should be recognised as disease, where disease is recognised as a deviation from the biological norm in accordance with the criteria of the time period and the social culture (Schramme, 2012; Ibeneme et al., 2017; Habersack \& Luschin 2013; Wilensky \& Teitelbaum, 2020). Thus, health is a benefit characteristic of any person; only the level of health is different. According to the general principle, a person with health disorders should also be considered healthy if this corresponds to their perception and if the person is able to fulfil their needs to the extent acceptable to them. And society, taking into account the consideration of public safety, as well as public interest, should have the right to set a limit up to which an individual's own initiative for assessing their own health is acceptable. Over this limit, the person is not recognised as completely healthy; their health should be assessed in the particular situation regardless of their own beliefs but considering the objective criteria defined by society.

This raises the question, when is it determined whether a person is healthy. From social and legal norms follows the idea what a person should be like. Good health and emotional comfort are better than ill health and emotional discomfort where appearance of illness is subject to particular laws, finding a natural explanation for it, and illness needs to be diagnosed (Brazier, 1992; Gaile \& van Hofa, 2003; Rumpelsberger, 2012). It can thus be concluded that health is a benefit characteristic of a person while the opposite has not been proven. And health is one of the elements of the set of benefits characteristic of each individual 
in society. For example, one such element is also a person's legal capacity where the presumption of legal capacity exists (Mazure, 2014; see: Crewe (Re), 2007 NSSC 322, 2007; Hospitals Act of Nova Scotia, 1989) while it has not been disproven due to the person's health. Although illness applies to the entire human body, with the interaction of organ systems, still, a specific disease is diagnosed where a specific level of health thus forms for the particular individual. It is thus presumed that a person has complete health while they have not been diagnosed with a specific disease, forming the person's specific level of health.

The definition of human health proposed by the WHO includes three forms of human well-being - physical, mental, and social. Understanding of human health is nowadays expanding, describing the idea in more detail. Five elements of human health are derived from the categories of the body, mind, soul, family, society, education, and belief: 1) emotional or mental, i.e. the ability to understand, solve problems, study and work, as well as the sense of humour; 2) intellectual, i.e. the ability to obtain information, process it and make decisions (this element stands out from emotional); 3) spiritual, i.e. the ability to have internal harmony; 4) physical, i.e., the condition of the body, its ability to resist to ill conditions (the ability to perform the necessary life functions - Author's note); 5) social, i.e., the ability to be part of society, to be responsible, to communicate (the ability to socialise - Author's note) (Apostu, 2013; Žukovs et al., 1969; Baldunčiks \& Pokrotniece, 1999; Svalastog et al., 2017; Health, 2019b; Molineux, 2017; Müller, Ganten, \& Larisch, 2014). These elements of human health are actually concluded from the idea of "best interest". It is described as something a reasonable person would want; and considering that there is no such reasonable person, the idea is fiction filled with content by society; and people always possess this "best interest", regardless of their legal capacity (Mason \& McCall Smith, 1994; Kennedy \& Grubb, 1998). Nowadays, with the development of medicine, understanding of society about a person's "best interest" is also changing, becoming deeper and more diverse. And to achieve this interest a person is given additional abilities, including these in the notion of health. Thus, human health is a state that allows implementing the following abilities emotional, intellectual, spiritual, physical, and social, expanding the understanding of human health.

There is controversy regarding the proportion of the abilities included in the understanding of human health and those to be achieved. Clearly, the opinion that these abilities interact with each other (Apostu, 2013) can be supported because human organ systems are strongly interconnected. However, there is also a belief that the predominant element of human health is the physical element in particular where the human body is the informative indicator (Barinov, Kosukhina, \& Mikheyeva, 2016). This is explained by the fact that a person's physical ability is easier to prove; whereas mental ability is difficult to determine, losing the strong 
connection with the evidence-based medical science (Jackson, 2013; Ottendörfer, 2016); the spiritual and social abilities are interpreted differently depending on the values of a particular society. Still, regardless of the fact that each element of human health is important, where, for example, emotional harm can often be deeper and longer-lived than physical harm (R.v.L.K., 2011 ONSC 3056, 2011), problems in the spiritual element can make the functioning of the other elements, as well as the entire human body, significantly more difficult. Trying to understand the desirable proportion of the elements of human health, two principles have been found for determining this proportion: firstly, the importance of lifestyle for maintaining health is emphasised even in the Hippocratic Oath, and it is still stressed nowadays (Gaile \& van Hofa, 2003; Apostu, 2013); secondly, the idea of balance in health is proposed (Wellbeing, 2019; Welfare, 2019; Gangl, 2015; Sartorius, 2006; Ibeneme et al., 2017). It can thus be concluded that predominance of any element in the understanding of human health, thus viewing it in isolation from the human body, should not be supported. The physical, emotional, intellectual, spiritual, and social element of human health should be determined as a proportion, on the basis of two principles, i.e., lifestyle as a measure and balance as a criterion in the implementation of lifestyle.

With the expanding understanding of human health, which opens up many more detailed elements of health, we need to evaluate the legal nature of the concept of health nowadays. Even though promoting medical technology and pharmaceutical industry with the understanding of health is criticised, still it is recognised that medical intervention is required to correct deviations in health (Huber, Knottnerus, Green, van der Horst, Jadad, Kromhout et al., 2011; Misselbrook, 2014; Müller et al., 2014) by attributing the understanding of health and health promoting activities in western society to scientific rationalism (Ibeneme et al., 2017). Thus, medical understanding of health prevails. However, we have to agree with the opinion about the formation of the interdisciplinary nature of health (Büchs \& Koch, 2019; Den Exter, 2002) where understanding of health is expanding and the medical science nowadays no longer covers full interpretation of health. Thus, health is an interdisciplinary concept which preserves the medical nature of health as the prevailing one in its scientific explanation.

One of the drawbacks of the definition of human health is that the definition does not reflect individual's personal involvement and its meaning in maintaining and improving health. Even though the right to health does not mean or guarantee the right to be healthy, still every individual is entitled to the highest level of health that can be achieved (The Right to Health, 2008; Starptautiskais pakts par pilsoniskajām un politiskajām tiesībām, 1966; Eiropas Sociālā harta, 1961). Moreover, there is an opinion that a person who does not strive for health will not become ill because they are already ill (Hahn, 2013). Thus, human desire to be 
healthy or as healthy as possible is presumed to obviously correspond to public values where the opposite action is considered a deviation from the common norm.

Health is an individual's highest good which forms the starting position for their possible further action (Hahn, 2013; Buijsen, 2000), which is characterised by the following action escalation stages. At the beginning, health provides the strength to be and the state for action (Gangl, 2015; Nordenfelt, 2007; Misselbrook, 2014). At the next stage, health provides the ability to be autonomous (Rumpelsberger, 2012), which expands the scope of initial action. Where as by implementing autonomy, health provides the person with the basis for maximum individual self-fulfilment and social self-realisation (Montgomery, 1997; Parson, 1967; Svalastog et al., 2017; Rumpelsberger, 2012; Ibeneme et al., 2017). The scope of abilities to act related to health can be developed and improved (Sartorius, 2006; Kabaeva, 2011; Müller et al., 2014), thus achieving the next action escalation stage. Such definition supports the understanding of active and interactive health where the individual is seen as a dynamic rather than passive system (Svalastog et al., 2014; The Ottawa Charter for Health Promotion, 1986; Gangl, 2015; Kennedy \& Grubb, 1998). Thus, the definition of human health should include the idea of dynamics which manifests in two ways. On the one hand, health is not a frozen state where a person has the opportunity to achieve the highest level of health. On the other hand, health itself provides the basis for a person's action with different possible stages of escalation. Human health strongly interacts with a person's actions where the results are mutually dependent.

\section{Research results and conclusions}

1. The legal definition of human health does not cover significant and already existing principles of health, which is why this definition is believed to be too narrow and imprecise. For an objective and comprehensive understanding of human health, the definition should include the following principles:

a) Health is characteristic of each individual; however, with actually different levels;

b) Complete health is presumed for a person;

c) A person possesses self-determination in the evaluation of their own health to an objective limit determined by society;

d) Health provides the basis for a person's action with different escalation levels depending on the person's level of health;

e) A person has the opportunity to strive to achieve the highest level of health, i.e. maintain and improve it. 
2. With the understanding of human health expanding, new principles describing human health appear nowadays. This is why the legal definition of human health should include more detailed principles in accordance with the modern legal system. These are the following:

a) Health is the state of a person's organism;

b) Health is a complete rather than an absolute state;

c) Health is the state that allows implementing the emotional, intellectual, spiritual, physical, and social ability;

d) Elements of health are interrelated with the principle of balance among them, which is achieved through lifestyle as a measure;

e) Health is an interdisciplinary concept where the prevalence of the medical explanation is preserved.

3. When analysing the legal definition of human health, it needs to be adjusted in accordance with the modern legal system. Firstly, this definition should include already existing objective principles of human health. Secondly, the definition of human health should be completed with innovative modern principles of the understanding of human health.

Revise the first sentence of Section 3(1) of the Medical Treatment Law as follows:

"Section 3. (1) Health is a complete state of a person's organism, which, depending on the person's level of health, allows them to implement in a balance through lifestyle the emotional, intellectual, spiritual, physical, and social ability, presuming complete health for each individual while the opposite has not been proven via medical testing, and where the person's aim is to achieve the highest level of health objectively possible."

\section{References}

Apostu, M. (2013). New Points of View on Concept of Health and Lifestyle. Procedia - Social and Behavioral Sciences, 92, 50-54. DOI: 10.1016/j.sbspro.2013.08.636.

Ārstniecības likums. (1997). LR likums. Latvijas Vēstnesis, 167/168, 3.p.pirmā daḷa.

Baldunčiks, J., \& Pokrotniece, K. (1999). Svešvārdu vārdnīca: vairāk nekā 15000 citvalodu cilmes vārdu un terminologisku vārdkopu. Rīga: Jumava.

Barinov, E.H., Kosukhina, O.I., \& Mikheyeva, N.A. (2016). Reshenie problemy grazhdanskogo pravovogo regulirovanija deliktnyh otnoshenij voznikajushhih pri okazanii mediciskoj pomoshi. Mediciskoe pravo, 1(3), 28-31.

Brazier, M. (1992). Medicine, patients and the law. Harmondsworth: Penguin Books.

Buijsen, M. (2000). The Concept of Health Law. Frontiers of European health law: yearbook. European Centre for Advanced Legal Studies in Health Care. Rotterdam: Erasmus University Press, 4-9. 
Büchs, M., \& Koch, M. (2019). Challenges for the degrowth transition: The debate about wellbeing. Futures, 105, 155-165. Doi: https://doi.org/10.1016/j.futures.2018.09.002.

Constitution of the World Health Organization. (1946). The World Health Organization. Preamble. Retrieved from https://www.who.int/governance/eb/who_constitution_en.pdf

Crewe (Re), 2007 NSSC 322. (2007). The Judgment of the Supreme Court of Nova Scotia, Canada. Retrieved from https://www.canlii.org/en/ns/nssc/doc/2007/2007nssc322/2007nssc322.html .

Den Exter, A. (2002). The Right to Health Care in International Law. Frontiers of European health law: yearbook. European Centre for Advanced Legal Studies in Health Care. Rotterdam: Erasmus University Press, 12-26.

Eiropas Sociālā harta. (1961). Starptautiskais tiesību akts. Pieejams https://likumi.lv/ ta/lv/starptautiskie-ligumi/id/1045

Gaile, A., \& van Hofa, A. (2003). Hipokrātiskie raksti: izlase. Rīga: Liepnieks \& Rītups.

Gangl, V. (2015). "Gesundheit" ist mehrdimensional. Grundlagen einer Gesundheitsbildung. Magazin Erwachsenenbildung.at, 24. Retrieved from: https://www.pedocs.de/ volltexte/2015/10361/pdf/Erwachsenenbildung_24_2015_Gangl_Gesundheit_ist_mehrd imensional.pdf

Habersack, M., \& Luschin G. (2013). WHO-definition of health must be enforced by national law: a debate. BMC Med Ethics, 14, 24. DOI: 10.1186/1472-6939-14-24.

Hahn, D. (2013). Prinzip Selbstverantwortung? Eine Gesundheit für alle? Verschiebungen in der Verantwortung für Gesundheit im Kontext sozialer Differenzierungen. Jahrbuch für kritische Medizin und Gesundheitswissenschaften, 46, 29-50. Retrieved from http://www.med.uni-magdeburg.de/jkmg/wp-content/uploads/2013/03/JKMG_Band46_ Kapitel04_Hahn.pdf

Health. (2019a). Cambridge Dictionary. Retrieved from https://dictionary.cambridge.org/ dictionary/english/health

Health. (2019b). The Merriam-Webster.com Dictionary. Retrieved from https://www.merriamwebster.com/dictionary/health

Hospitals Act of Nova Scotia. (1989). Canada. Retrieved from www.canlii.org/en/ns/ laws/stat/rsns-1989-c-208/79929

Huber, M., Knottnerus, J.A., Green, L., van der Horst, H., Jadad, A.R., Kromhout, D., et al. (2011). How should we define health? BMJ, 343. DOI: https://doi.org/ 10.1136/bmj.d4163

Ibeneme, S., Eni, G., Ezuma, A., \& Fortwengel, G. (2017). Roads to Health in Developing Countries: Understanding the Intersection of Culture and Healing. Current Therapeutic Research, 86, 13-18. Retrieved from https://doi.org/10.1016/j.curtheres.2017.03.001

Jackson, E. (2013). Medical law: text, cases, and materials. Oxford: Oxford University Press.

Jakarta Declaration on Leading Health Promotion into the 21st Century. (1997). The Fourth International Conference on Health Promotion: New Players for a New Era - Leading Health Promotion into the 21st Century. Retrieved from https://www.who.int/ healthpromotion/conferences/previous/jakarta/declaration/en/

Kabaeva, V.M. (2011). Ponjatie zdorov'ja $v$ filosofii $i$ medicine. Retrieved from https://superinf.ru/view_helpstud.php?id=1417

Kennedy, I., \& Grubb, A. (1998). Principles of medical law. Oxford: Oxford University Press.

Lock, S., Last, J.M., \& Dunea, G. (2006). The Oxford Companion to Medicine (3 ed.). Oxford: Oxford University Press. Retrieved from https://www.oxfordreference.com/search?q= health+definition\&searchBtn=Search\&isQuickSearch=true 
Mason, J.K., \& McCall Smith, R.A. (1994). Law and Medical Ethics. London, Dublin, Edinburgh: Butterworths.

Mazure, L. (2014). Pacienta griba un tās civiltiesiskā aizsardzība. Rēzekne: RA Izdevniecība.

Misselbrook, D. (2014). W is for Wellbeing and the WHO definition of health. British Journal of General Practice, 64(628), 582. DOI: 10.3399/bjgp14X682381.

Molineux, M. (2017). A Dictionary of Occupational Science and Occupational Therapy. Oxford: Oxford University press.

Montgomery, J. (1997). Health care law. Oxford: Oxford Clarendom Press.

Müller, A. (2012). Was ist Gesundheit? Retrieved from http://www.dr-anke-persson.de/wasist-gesundheit.html

Müller, R., Ganten, D., \& Larisch, J. (2014). Public Health: Gesundheit ist mehr als Medizin. Dtsch Arztebl, 111(44), A1900-A1903. Retrieved from https://www.aerzteblatt.de/ archiv/163282/Public-Health-Gesundheit-ist-mehr-als-Medizin

Nordenfelt, L. (2007). Understanding the concept of health. Dept of Health and Society, Linköping University. Retrieved from https://www.fil.lu.se/hommageawlodek/ site/papper/NordenfeltLennart.pdf

Ottendörfer, B. (2016). Wissensbasis für den Diskurs von Armut und Gesundheit. Johannes Kepler Universität Linz, Institut für Gesellschafts- und Sozialpolitik. Retrieved from http://www.oegkk.at/cdscontent/load?contentid=10008.636573\&version=1543280429

Parson, T. (1967). Definition von Gesundheit und Krankheit im Lichte der Wertbegriffe und der sozialen Struktur Amerikas. In Mitscherlich, A., Brocher, T., von Mering, O., \& Horn, K. (Eds.), Der Kranke in der modernen Gesellschaft (pp. 57-87). Köln, Berlin: Kiepenheuer \& Witsch.

Rogers, A., Castree, N., \& Kitchin, R. (2013). A Dictionary of Human Geography. Oxford: Oxford University Press. Retrieved from https://www.oxfordreference.com/view/ 10.1093/acref/9780199599868.001.0001/acref-9780199599868-e2038?rskey=ETZW2Y\&result=2037

Rumpelsberger, K. (2012). Gesund ist, wer nicht krank ist? Subjektive Gesundheitsvorstellungen oberösterreichischer Hausärzte und ihre gegenwärtige und zukünftige Rolle. Universität Bielefeld, Dissertation. Retrieved from https://pub.unibielefeld.de/download/2498340/2498351/RumpelsbergerDruckvorl.pdf

R.v.L.K., 2011 ONSC 3056. (2011). The Judgment of the Superior Court of Justice, Ontario, Canada. Retrieved from http://canlii.ca/t/flqr3

Sartorius, N. (2006). The Meanings of Health and its Promotion. Croat Med J, 47(4), 662-664. Retrieved from https://www.ncbi.nlm.nih.gov/pmc/articles/PMC2080455/

Schramme, T. (2012). Krankheitstheorien. Berlin: Suhrkamp Verlag.

Starptautiskais pakts par pilsoniskajām un politiskajām tiesībām. (1966). Starptautiskais tiesību akts. Retrieved from https://www.mfa.gov.lv/ministrija/latvijas-parstavisstarptautiskajas-cilvektiesibu-institucijas/latvijas-republikas-nacionalie-zinojumi-parstarptautisko-konvenciju-izpildi/1966-gada-starptautiskais-pakts-par-pilsoniskajam-unpolitiskajam-tiesibam

Svalastog, A.L., Donev, D., Kristoffersen N.J., \& Gajovič, S. (2017). Concepts and definitions of health and health-related values in the knowledge landscapes of the digital society. Croat Med J., 58(6), 431-435. DOI: 10.3325/cmj.2017.58.431.

The Ottawa Charter for Health Promotion. (1986). First International Conference on Health Promotion, Ottawa. Retrieved from https://www.who.int/healthpromotion/conferences/ previous/ottawa/en/ 
The Right to Health. (2008). Fact Sheet No.31. World Health Organization, Switzerland. Retrieved from https://www.ohchr.org/Documents/Publications/Factsheet31.pdf

Veterans Health Care Regulations. (1990). Department of veterans affairs act, Canada, SOR/90594. Retrieved from https://laws-lois.justice.gc.ca/eng/regulations/SOR-90-594/page1.html?txthl=definition+health\#s-2

Welfare. (2019). Dictionary.com. Retrieved from https://www.dictionary.com/browse/welfare

Wellbeing. (2019). Dictionary.com. Retrieved from https://www.dictionary.com/browse/ wellbeing

Wilensky, S.E., \& Teitelbaum, J.B. (2020). Essentials of health policy and law. Fourth edition. Editor Riegelman R. Burlington: Jones \& Bartlett Learning.

Žukovs, L. et al. (1969). Svěsvārdu vārdnīca: ap 16500 citvalodu cilmes vārdu un terminologisku savienojumu. Rīga: Liesma. 